\title{
PENGARUH LAMA PEMANASAN TERHADAP VITAMIN C, AKTIVITAS ANTIOKSIDAN DAN SIFAT SENSORIS SIRUP KERSEN (Muntingia calabura L.)
}

\author{
[The Effect of Boiling Time on Vitamin C, Antioxidant Activity and Sensory Properties of \\ Singapore Cherry (Muntingia calabura L.) Syrup] \\ Rizki Ameliya*, Nazaruddin, Dody Handito \\ Program Studi Ilmu dan Teknologi Pangan, Fakultas Teknologi Pangan dan Agroindustri, Universitas Mataram \\ *Email: ameliyamusthafa@gmail.com
}

Diterima 12 November 2017/ Disetujui 24 April 2018

\begin{abstract}
The aim of this research was to determine the effect of boiling time on vitamin C, antioxidant activity, reduction sugar, $\mathrm{pH}$ and sensory properties (tastes and aroma) of singapore cherry (Muntingia calabura L.) syrup. The experimental design used was Completely Randomized Design (CRD) one factor (boiling time) consist of five treatments: P1 (20 minute), P2 (30 minute), P3 (40 minute), P4 (50 minute), P5 (60 minute). The observed parameters were vitamin C, antioxidant activity, reduction sugar, $\mathrm{pH}$ and sensory properties (tastes and aroma with hedonic and scoring test). The data were analyzed using analysis of variance at 5\% confident level with Co-Stat software. The significant data were analyzed using Honestly Significant Differences (HSD) test. The result showed that boiling time gave a significant effect on pH, vitamin C, antioxidant activity and reduction sugar but didn't significant on sensory properties (tastes and aromas). The best treatment was boiling time for 20 minutes that resulted in the highest value of vitamin C $(28.09 \mathrm{mg} / 100 \mathrm{~g}$ material) and antioxidant activity (51.79\%). Meanwhile the reduction sugar was $7.95 \%, \mathrm{pH} 4.28$, the taste was rather sweet and the aroma was rather specific of Singapore cherry.
\end{abstract}

Keywords: antioxidant, Singapore cherry, syrup, vitamin C.

\section{ABSTRAK}

Penelitian ini bertujuan untuk mengetahui pengaruh lama pemanasan (perebusan) terhadap kadar vitamin $\mathrm{C}$, aktivitas antioksidan, gula reduksi, pH dan sifat sensoris (rasa dan aroma) sirup kersen (Muntingia calabura L.). Rancangan percobaan yang digunakan adalah Rancangan Acak Lengkap (RAL) dengan satu faktor yaitu lama pemanasan (perebusan) yang terdiri dari lima perlakuan, meliputi; P1 (20 menit), P2 (30 menit), P3 (40 menit), P4 (50 menit), P5 (60 menit). Parameter yang diamati meliputi vitamin $\mathrm{C}$, aktivitas antioksidan, gula reduksi, $\mathrm{pH}$ dan sifat sensoris rasa dan aroma (metode hedonik dan scoring) sirup kersen. Data hasil pengamatan diuji dengan analisis keragaman pada taraf nyata $5 \%$ menggunakan software Co-Stat. Apabila hasil pengamatan terdapat perbedaan yang nyata, maka diuji lanjut menggunakan uji Beda Nyata Jujur (BNJ). Hasil penelitian menunjukkan bahwa perlakuan lama perebusan memberikan pengaruh yang berbeda nyata (signifikan) terhadap pH, vitamin $\mathrm{C}$, aktivitas antioksidan dan gula reduksi namun memberikan pengaruh yang tidak berbeda nyata (non signifikan) terhadap sifat sensoris rasa dan aroma (uji hedonik dan scoring) sirup kersen. Perlakuan terbaik adalah lama perebusan 20 menit karena menghasilkan sirup kersen dengan vitamin $\mathrm{C}$ tertinggi $(28,09$ $\mathrm{mg} / 100 \mathrm{~g}$ bahan) dan aktivitas antioksidan tertinggi $(51,79 \%)$, gula reduksi $7,95 \%$, pH 4,28, rasa agak manis dan aroma agak khas kersen.

Kata kunci: antioksidan, kersen, sirup, vitamin C.

\section{PENDAHULUAN}

Pohon kersen (Muntingia calabura L.) adalah tanaman jenis neotropik yaitu suatu jenis tanaman yang tumbuh baik di daerah tropis seperti Indonesia. Tanaman kersen berasal dari Filipina dan dilaporkan masuk ke Indonesia pada abad ke-19. Kersen merupakan pohon yang dapat tumbuh dengan ketinggian 3- $12 \mathrm{~m}$ dan berbuah dengan cepat sepanjang tahun. Buahnya bertipe buah buni, berwarna merah kusam, berdiameter $15 \mathrm{~mm}$, berisi beberapa ribu biji yang kecil di dalam daging buah yang lembut (Verheij dan Coronel, 1997).

Kersen termasuk buah tropis dan dapat dimakan dengan rasa manis dan aroma yang khas. Di dalam $100 \mathrm{~g}$ kersen mengandung rata- rata 76,3 g air,2,1 g protein, 2,1 g lemak, $17,9 \mathrm{~g}$ karbohidrat, 6,0 g serat, $1,4 \mathrm{~g}$ abu, $125 \mathrm{mg}$ kalsium, $94 \mathrm{mg}$ fosfor, 0,015 mg vitamin $A, 90 \mathrm{mg}$ vitamin $\mathrm{C}$. Nilai energi adalah $380 \mathrm{~kJ} / 100 \mathrm{~g}$ (Rahman dkk., 2010). Kandungan vitamin $\mathrm{C}$ yang terkandung dalam buah kersen bermanfaat untuk memperbaiki kerusakan jaringan endothel dan menurunkan kadar trigliserida pada penderita dislipidemia 
sehingga buah ini sangat berpotensi untuk ditingkatkan komoditasnya dengan diolah menjadi jus dan dijadikan minuman fungsional (Maghribi, 2013).

$$
\text { Pramono dan Santoso (2014) }
$$

menyebutkan bahwa pemanfaatan buah kersen khususnya di Indonesia masih sangat kurang padahal jika mengacu dari komposisi buah, sebenarnya buah kersen dapat dimanfaatkan dengan baik karena keberadaannya yang melimpah dan dapat tumbuh di mana saja. Selain itu, buah kersen sebagian besar mengandung air, sehingga buah ini tidak dapat dikonsumsi dalam waktu yang lama setelah dipetik. Supaya dapat menghasilkan nilai tambah dari buah kersen, perlu adanya inovasi dalam pemanfaatan buah kersen. Salah satunya dibuat sebagai bahan baku dalam pembuatan sirup buah.

Sirup adalah produk minuman yang dibuat dari campuran air dan gula dengan kadar larutan gula minimal $65 \%$ dengan atau tanpa bahan pangan lain dan atau bahan tambahan pangan yang diijiinkan sesuai ketentuan yang berlaku (SNI 3544:2013). Menurut Satuhu (1994) definisi sirup yang lain yaitu sejenis minuman ringan berupa larutan kental dengan citarasa beraneka ragam, biasanya mempunyai kandungan gula minimal $65 \%$. Berdasarkan bahan baku, sirup dibedakan menjadi tiga, yaitu sirup essens, sirup glukosa, dan sirup buah- buahan. Sirup buah adalah sirup yang aroma dan rasanya ditentukan oleh bahan dasarnya yaitu buah segar. Di dalam proses pembuatan sirup selalu melibatkan proses pemanasan. Namun proses pemanasan yang terlalu lama akan menyebabkan terjadinya degradasi atau penurunan senyawa gizi atau non gizi yang berasal dari buah khususnya senyawa yang sensitif terhadap proses pemanasan yaitu vitamin $\mathrm{C}$ dan senyawa antioksidan.

Hartiati dkk. (2009) menyebutkan bahwa sirup bunga rosella yang dipanaskan pada suhu $100^{\circ} \mathrm{C}$ dengan waktu perebusan 30 menit dan 20 menit menghasilkan aktivitas antioksidan sirup bunga rosella yang lebih tinggi. Trissanthi dan Wahono (2016) menyebutkan pengaruh lama pemanasan terhadap karakteristik kimia dan organoleptik sirup alang-alang menunjukkan bahwa sirup alang-alang yang dipanaskan pada suhu $\pm 100^{\circ} \mathrm{C}$ dengan lama pemanasan 40 menit menghasilkan aktivitas antioksidan paling tinggi yakni sebesar 13,06 $\%$. Aktivitas antioksidan yang dihasilkan cenderung menurun dengan semakin lamanya
ISSN: 2443-1095

pemanasan dikarenakan selama proses pemanasan terjadi kerusakan senyawasenyawa yang memiliki aktivitas antioksidan.

Tujuan penelitian ini adalah untuk mengetahui pengaruh lama pemanasan (perebusan) terhadap vitamin $\mathrm{C}$, aktivitas antioksidan, gula reduksi, $\mathrm{pH}$ dan sifat sensoris (rasa dan aroma) sirup kersen (Muntingia calabura L.).

\section{METODOLOGI}

\section{Bahan dan Alat}

Bahan yang digunakan dalam penelitian ini adalah buah kersen yang berasal dari Lokok Gitak, Dusun Karang Pendagi, Desa Gondang, Kecamatan Gangga Kabupaten Lombok Utara, gula pasir merek Gulaku, asam sitrat cap Gajah dan CMC cap Koepoe-Koepoe yang dibeli di toko Yaoya, air mineral merek Narmada dari toko Ruby, aquades, methanol (p.a), larutan Iod 0,01 N (p.a), larutan DPPH $0,5 \mathrm{mM}$ (p.a), reagen Luff-Schrool (p.a), KI $20 \%$ (p.a), larutan $\mathrm{H}_{2} \mathrm{SO}_{4} \quad 26,5 \%$ (p.a), larutan $\mathrm{Na}_{2} \mathrm{~S}_{2} \mathrm{O}_{3} \quad 0,1 \mathrm{~N}$ (p.a) dan indikator amilum $1 \%$ (p.a).

Alat-alat yang akan digunakan dalam penelitian ini adalah baskom, blender merk Philips, botol $200 \mathrm{~mL}$, kain saring, panci, kompor gas merk Rinnai, refrigerator merk Flocchetti, stopwatch, pengaduk, cup plastic, corong, timbangan merk Five Goats, timbangan analitik merk Kern, pH meter merk Schott, tabung reaksi, rak tabung reaksi, erlenmeyer $100 \mathrm{~mL}$, erlenmeyer $250 \mathrm{~mL}$, erlenmeyer $300 \mathrm{~mL}$, labu ukur $100 \mathrm{~mL}$, labu ukur $1.000 \mathrm{~mL}$, aluminium foil, alat titrasi, pipet tetes, pemanas balik, kertas saring, hotplate merk IEC, hotplate stirrer merk Heidolph, stirrer, vortex merk Heidolph, batu magnet, sentrifugasi, gelas beker $50 \mathrm{~mL}$, gelas beker $100 \mathrm{~mL}$, gelas beker $250 \mathrm{~mL}$, gelas beker $500 \mathrm{~mL}$, gelas beker $1000 \mathrm{~mL}$, gelas beker $200 \mathrm{~mL}$, pipet volume $10 \mathrm{~mL}$, pipet volume $25 \mathrm{~mL}$, pipet ukur $10 \mathrm{~mL}$, pipet ukur $5 \mathrm{~mL}$, spektrofotometer UV-Vis tipe evolution 201 merk Thermo, kuvet, plastik, kertas label dan tisu.

\section{Rancangan Percobaan}

Metode yang digunakan dalam penelitian ini adalah metode eksperimental yang dilaksanakan di laboratorium. Rancangan yang digunakan dalam penelitian ini adalah Rancangan Acak Lengkap (RAL) yang terdiri atas 5 aras dengan faktor tunggal yaitu pengaruh variasi suhu pengeringan. Perlakuannya yaitu suhu pengeringan $50^{\circ} \mathrm{C}$ 
$(\mathrm{P} 1)$, suhu pengeringan $55^{\circ} \mathrm{C}(\mathrm{P} 2)$, suhu pengeringan $60^{\circ} \mathrm{C}(\mathrm{P} 3)$, suhu pengeringan $65^{\circ} \mathrm{C}(\mathrm{P} 4)$ dan suhu pengeringan $70^{\circ} \mathrm{C}(\mathrm{P} 5)$.

$$
\text { Parameter yang diamati dalam }
$$

penelitian ini adalah kualitas teh katuk meliputi sifat kimia, fisik dan organoleptik. Sifat kimia meliputi kadar air dan aktivitas antioksidan. Sifat fisik meliputi ekstrak larut dalam air dan sifat organoleptik meliputi rasa, aroma dan warna dengan menggunakan metode afektif dan deskriptif. Data hasil pengamatan dianalisis menggunakan analisis keragaman (Analysis of Variance) pada taraf nyata $5 \%$. Bila terdapat perbedaan nyata, maka diuji lanjut dengan uji Beda Nyata Jujur (BNJ) pada taraf yang sama.

\section{Tahapan Penelitian}

Adapun proses pembuatan sirup buah menurut Indrayani (2012) yang telah dimodifikasi adalah sebagai berikut:

Bahan baku utama pada pembuatan sirup buah adalah buah kersen matang yang didapat dari Lokok Gitak, Desa Gondang, Kecamatan Gangga Kabupaten Lombok Utara.

\section{Sortasi (pemilihan buah)}

Buah kersen disortasi untuk memisahkan buah dengan kualitas yang baik. Buah kersen yang akan diolah adalah buah yang sudah masak dan lunak sehingga banyak menghasilkan sari buah dan aromanya bagus. Di mana untuk setiap perlakuan digunakan buah kersen sebesar $1,5 \mathrm{~kg}$.

\section{Pencucian}

Buah kersen $1,5 \mathrm{~kg}$ yang telah disortasi dicuci dengan air yang mengalir sampai bersih. Pencucian ini bertujuan untuk membersihkan kotoran-kotoran yang masih melekat pada buah.

\section{Penghancuran buah dan penyaringan}

Buah kersen yang sudah bersih kemudian dimasukkan ke dalam waring blender untuk dihancurkan atau dihaluskan. Buah yang telah dihancurkan ditambah air 1,5 $\mathrm{L}$, kemudian disaring sambil ditekan-tekan sehingga keluar sari buahnya.

\section{Pemanasan}

Sari buah kersen 2 L ditambahkan bahan tambahan (gula $375 \mathrm{~g}$, CMC 0,45 g dan asam sitrat $3 \mathrm{~g}$ untuk setiap perlakuan), kemudian dipanaskan dengan cara direbus pada suhu $100^{\circ} \mathrm{C}$ dengan perlakuan waktu perebusan yang diberikan, yaitu 20,30,40,
50 dan 60 menit. Modifikasi proses pengolahan pembuatan sirup dilakukan pada tahap penambahan CMC dan asam sitrat. Pada Indrayani (2012) penambahan asam sitrat dan CMC dilakukan setelah sirup selesai direbus, sedangkan pada penelitian ini penambahan CMC dan asam sitrat dilakukan lima menit sebelum proses perebusan selesai.

\section{Pengemasan}

Setelah proses perebusan selesai, 200 $\mathrm{mL}$ sirup buah ke dalam botol yang telah disiapkan. Botol yang digunakan untuk mengemas produk sirup disterilkan lebih dahulu dengan cara direbus pada suhu $100^{\circ} \mathrm{C}$ selama 30 menit. Proses pengisian sirup ke dalam botol harus dilakukan dengan cara hotfilling yaitu memasukkan sirup buah kersen pada saat dalam keadaan masih panas. Kemudian segera ditutup dan dilakukan penurunan suhu menggunakan air mengalir dan sirup telah siap untuk dianalisis. Parameter yang dianalisis meliputi vitamin $\mathrm{C}$ (AOAC, 1999), aktivitas antioksidan (Osawa, 1981), gula reduksi (Sudarmaji dkk., 2010), pH (BSN, 2004) dan sifat sensoris (aroma dan rasa) (Nurrahman dkk., 2006) sirup kersen.

\section{HASIL DAN PEMBAHASAN}

\section{Kadar Vitamin C}

Vitamin C adalah nutrien dan vitamin yang larut dalam air dan penting untuk kehidupan serta untuk menjaga kesehatan. Vitamin ini juga dikenal dengan nama kimia dari bentuk utamanya yaitu asam askorbat. Vitamin $\mathrm{C}$ dikenal sebagai antioksidan terlarut air paling dikenal, vitamin C juga secara efektif memungut formasi ROS (Reactive Oxygen Species) dan radikal bebas (Frei, 1994). Dalam pengolahan bahan pangan, kehilangan vitamin $\mathrm{C}$ terbanyak terjadi akibat degradasi kimiawi. Dalam bahan pangan yang kaya akan vitamin C seperti pada buahbuahan, kehilangan biasanya berhubungan dengan reaksi pencoklatan non enzimatis.

Selama proses pengolahan dan penyimpanan vitamin $\mathrm{C}$ yang hilang diperkirakan sekitar 7-14 mg asam askorbat per $\mathrm{ml}$ sari buah (Deman, 1997). Hubungan pengaruh lama pemanasan (perebusan) dengan vitamin $C$ sirup kersen dapat dilihat pada Gambar 1. 


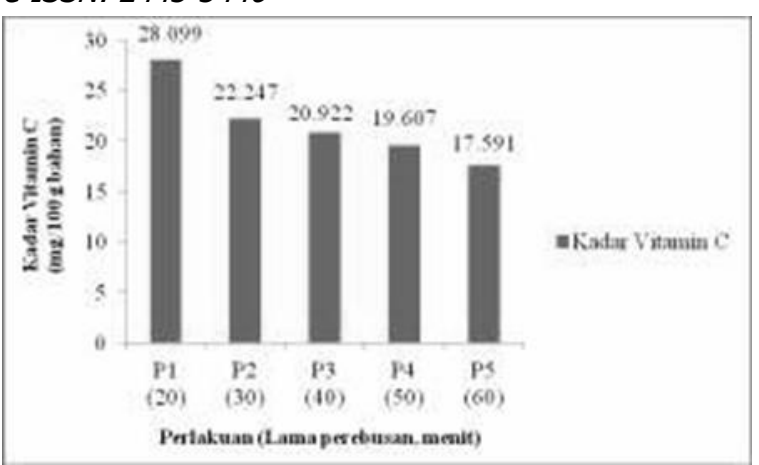

Gambar 1. Grafik Pengaruh Lama Pemanasan (Perebusan) terhadap Kadar Vitamin C Sirup Kersen

Berdasarkan Gambar 1, menunjukkan bahwa semakin lama waktu pemanasan (perebusan) maka kadar vitamin C sirup kersen semakin menurun. Hal ini disebabkan karena vitamin C merupakan vitamin yang mudah mengalami oksidasi terutama oleh proses pemanasan. Hal ini sesuai dengan pendapat Octaviani (2014) bahwa semakin tinggi suhu dan lama pemanasan menyebabkan degradasi vitamin $\mathrm{C}$ juga semakin besar. Oksidasi vitamin C (asam askorbat) akan mengubah asam askorbat menjadi asam L-dehidroaskorbat yang secara kimia sangat labil dan dapat mengalami perubahan lebih lanjut menjadi asam Ldiketogulonat yang tidak memiliki keaktifan vitamin C lagi.

Kandungan vitamin $\mathrm{C}$ buah kersen sebelum proses pengolahan sebesar 49,736 $\mathrm{mg} / 100 \mathrm{~g}$ bahan. Namun setelah proses pemanasan selama $20,30,40,50$ dan 60 menit menurun menjadi 28,009, 22,247, $20,922,19,067$ dan $17,591 \mathrm{mg} / 100 \mathrm{~g}$ bahan. Hal ini sesuai dengan Hadiwijaya (2017) pada penelitiannya tentang pembuatan sirup naga menyatakan bahwa kandungan vitamin $\mathrm{C}$ yang terdapat dalam sirup buah naga mengalami penurunan ketika telah diolah menjadi sirup buah naga diakibatkan oleh rusaknya vitamin $\mathrm{C}$ oleh proses pengolahan. Pengolahan sirup banyak melalui proses pemanasan yang dapat mengakibatkan turunnya kadar vitamin $\mathrm{C}$ yang terkandung di dalam sirup. Selanjutnya menurut Handayani (2011) selama proses pengolahan, vitamin C yang terdapat pada sirup buah menjadi banyak yang hilang karena terjadi proses oksidasi.

\section{Aktivitas Antioksidan}

Antioksidan merupakan senyawa pemberi elektron (electron donor) atau
ISSN: 2443-1095

reduktan. Senyawa ini memiliki berat molekul kecil tetapi mampu menginaktivasi berkembangnya reaksi oksidasi dengan cara mencegah terbentuknya radikal. Antioksidan juga merupakan senyawa yang dapat menghambat reaksi oksidasi, dengan mengikat radikal bebas dan molekul yang sangat reaktif. Akibatnya, kerusakan sel akan dihambat. Senyawa antioksidan alami yang telah terbukti memiliki potensi tinggi sebagai antioksidan adalah vitamin C, vitamin E, karotenoid dan senyawa polifenol seperti asam fenolat, flavonoid, tanin dan lignan. Hubungan pengaruh lama pemanasan (perebusan) dengan aktivitas antioksidan sirup kersen dapat dilihat pada Gambar 2.

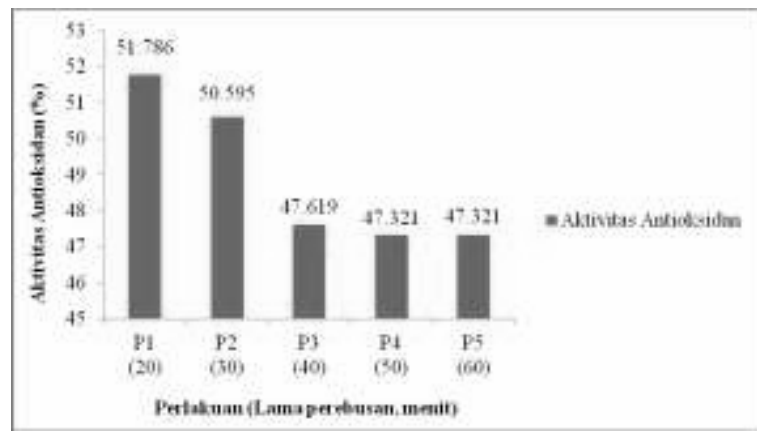

Gambar 2. Grafik Pengaruh Lama Pemanasan (Perebusan) terhadap Aktivitas Antioksidan Sirup Kersen

Berdasarkan Gambar 2, menunjukkan bahwa semakin lama waktu pemanasan (perebusan) maka aktivitas antioksidan sirup kersen semakin menurun. Hal ini disebabkan karena selama proses pemanasan terjadi kerusakan senyawa- senyawa yang memiliki aktivitas antioksidan di dalam produk. Menurut Gomathi dkk. (2011) bahwa buah kersen memiliki komponen bioaktif yang berpotensi sebagai sumber antioksidan karena kandungan vitamin $\mathrm{C}$ yang tinggi yaitu sebesar 33,6 mg AAE/g serta memiliki aktivitas antioksidan sebesar 85,71 $\pm 1,29 \%$ penghambatan. Namun terjadinya penurunan vitamin C selama pemanasan juga ikut menyebabkan penurunan aktivitas antioksidan produk sirup. Oksidasi vitamin $\mathrm{C}$ yang dipercepat oleh adanya pemanasan menyebabkan asam askorbat mengalami perubahan menjadi asam L- diketogulonat yang tidak memiliki keefektifan lagi sebagai vitamin C. Kandungan aktivitas antioksidan sirup kersen selama pemanasan 20, 30, 40, 50 dan 60 menit menurun menjadi $51,786 \%, 50,595 \%, 47,619 \%, 47,321 \%$ dan 47,321\%. Hal ini sesuai dengan Trissanthi dan 
Wahono (2016) bahwa aktivitas antioksidan yang dihasilkan cenderung menurun dengan semakin lamanya pemanasan. Selain itu, Hartiati dan Mulyani (2009) dalam penelitiannya tentang sirup bunga rosella menyatakan bahwa selama waktu perebusan dengan suhu tertentu senyawa-senyawa khususnya antioksidan yang terkandung dalam bunga rosella lebih banyak terekstrak.

Pemanasan juga dapat menyebabakan stabilitas pigmen buah menjadi terganggu. Pigmen diantaranya klorofil, karotenoid dan flavonoid (antocyanin dan anthoxantins) mempunyai peranan fungsional sebagai antioksidan. Senyawa flavonoid mudah larut dalam air dan banyak terdapat pada buah dan sayur berwarna ungu, merah dan biru seperti pada anggur, keluarga berri, plum, terung belanda, keluarga ceri, dan apel (Lozano, 2006). Buah kersen matang berwarna merah diketahui mengandung senyawa flavonoid sebesar 21,80 $\pm 1,84 \mathrm{mg} \mathrm{ME} / \mathrm{g}$ (Gomathi dkk., 2013). Temperatur dan cahaya termasuk faktor yang mempercepat kerusakan senyawa tersebut sehingga produk sirup kersen mengalami perubahan menjadi kecoklatan akibat degradasi senyawa flavonoid selama pemanasan.

\section{Kadar Gula Reduksi}

Gula reduksi merupakan senyawa penting dari karbohidrat yang mempunyai peran utama dalam penyediaan kalori bagi makhluk hidup dan merupakan senyawa utama yang dapat dijumpai pada tumbuhtumbuhan. Kadar gula reduksi yang tinggi dalam suatu bahan pangan ditandai dengan rasanya yang manis. Dengan demikian semakin manis rasa suatu produk maka semakin tinggi kadar gula reduksinya. Gula reduksi merupakan gula yang mampu mereduksi senyawa pengoksidasi, dengan kata lain gula ini sendiri mengalami oksidasi. Hubungan pengaruh lama pemanasan (perebusan) dengan kadar gula reduksi sirup kersen dapat dilihat pada Gambar 3.

Berdasarkan Gambar 3, menunjukkan bahwa semakin lama waktu pemanasan (perebusan) maka kadar gula reduksi sirup kersen semakin meningkat. Hal ini disebabkan karena semakin lama waktu pemanasan maka semakin banyak gula (sukrosa) yang terinversi menjadi glukosa dan fruktosa (gula reduksi). Hal ini sesuai dengan pendapat Harnowo dan Yunianta (2015) menyatakan bahwa sukrosa bersifat non pereduksi karena tidak mempunyai gugus $\mathrm{OH}$ bebas yang reaktif, namun selama pemanasan dan dengan adanya asam, sukrosa dapat terhidrolisis menjadi gula inversi yaitu fruktosa dan glukosa yang merupakan gula pereduksi.

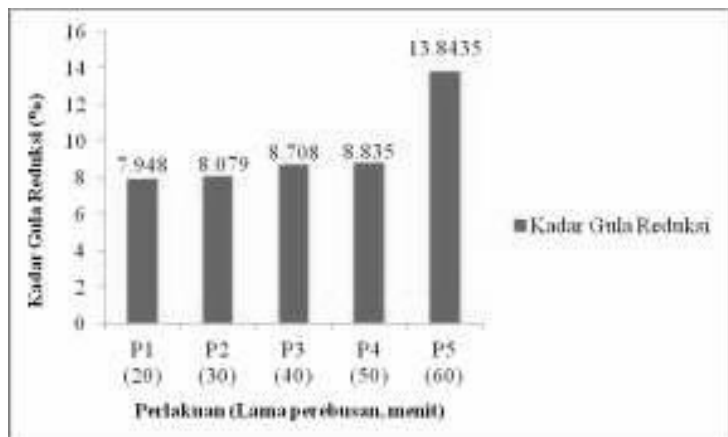

Gambar 3. Grafik Pengaruh Lama Pemanasan (Perebusan) terhadap Kadar Gula Reduksi Sirup Kersen

Kandungan gula reduksi sirup kersen selama pemanasan 20, 30, 40, 50 dan 60 menit meningkat yakni sebesar $7,948 \%, 8,079 \%, 8,708 \%, 8,835 \%$ dan $13,8435 \%$. Hal ini juga sesuai dengan Trissanthi dan Wahono (2016) dalam penelitiannya tentang sirup alang-alang bahwa kadar gula reduksi sirup alang-alang yang dihasilkan cenderung meningkat dengan semakin lamanya pemanasan. Pada pembuatan sirup, gula pasir (sukrosa) dilarutkan dalam air dan dipanaskan, sebagian sukrosa akan terurai menjadi glukosa dan fruktosa yang disebut gula invert.

\section{pH}

$\mathrm{pH}$ atau derajat keasaman digunakan untuk menyatakan tingkat keasaman atau basa yang dimiliki oleh suatu zat, larutan atau benda. Asam dan basa adalah besaran yang sering digunakan untuk pengolahan suatu zat, baik di industri maupun kehidupan sehari-hari. Pada industri kimia, keasaman merupakan variabel yang menentukan, mulai dari pengolahan bahan baku, menentukan kualitas produksi yamg diharapkan sampai pengendalian limbah industri agar dapat mencegah pencemaran pada lingkungan (Anonim, 2017b). pH merupakan tingkat keasaman yang akan mempengaruhi daya tahan suatu produk. Dapat dikatakan bahwa kadar asam yang tinggi ( $\mathrm{pH}$ yang rendah) disertai dengan total padatan terlarut yang tinggi seperti pada sirup merupakan teknik pengawetan pada produk. Pada $\mathrm{pH}$ rendah (kurang dari 4,6) mikroorganisme berbahaya seperti Clostridium botulinum akan sulit untuk tumbuh dan berkembang (Buckle, 2013). Hubungan pengaruh lama pemanasan 
(perebusan) dengan nilai $\mathrm{pH}$ sirup kersen dapat dilihat pada Gambar 4.

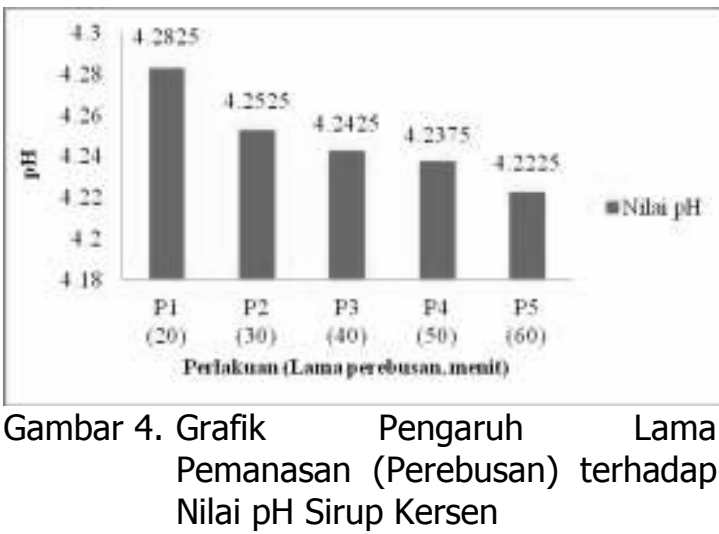

Berdasarkan Gambar 4, semakin lama waktu pemanasan (perebusan) maka nilai $\mathrm{pH}$ sirup kersen semakin menurun. Hal ini disebabkan karena peningkatan suhu akan menyebabkan adanya penambahan $\mathrm{H}^{+}$dalam larutan · Sehingga konsentrasi $\mathrm{H}^{+}$yang tinggi akan menyebabkan larutan menjadi asam atau $\mathrm{pH}$ menurun. Hal ini sesuai dengan pendapat Rahman dkk. (1992) bahwa penggunaan suhu yang lebih tinggi akan mempercepat penurunan $\mathrm{pH}$. Selain itu, penurunan $\mathrm{pH}$ juga disebabkan oleh adanya kandungan pati atau gula pada bahan dan penambahan asam sitrat. Molekul gula cenderung menarik partikel bermuatan negatif. Sifat tersebut terutama disebabkan oleh gugus-gugus hidroksilnya. Penarikan ion $\mathrm{OH}^{-}$kesekitar molekul gula akan mengakibatkan konsentrasi ion $\mathrm{H}^{+}$kedalam larutan meningkat sehingga nilai $\mathrm{pH}$ akan turun. Selain itu juga, asam sitrat yang ditambahkan ke dalam sirup kersen disamping berfungsi sebagai pengawet juga berfungsi sebagai pengatur keasaman. Mengatur $\mathrm{pH}$ sirup buah terutama yang menggunakan buah-buahan dengan tingkat keasaman yang rendah sehingga tidak cukup untuk menghasilkan $\mathrm{pH}$ seperti yang diinginkan.

\section{Rasa}

Uji sensoris merupakan salah satu uji yang digunakan untuk mengetahui tingkat penerimaan konsumen terhadap suatu produk. Rasa merupakan salah satu sifat sensoris yang penting karena menentukan penerimaan konsumen terhadap suatu produk. Rasa dari produk yang telah mengalami proses pengolahan seharusnya sesuai dengan rasa bahan baku utama yang digunakan. Hal ini berkaitan dengan ciri khas dan konsistensi dari bahan baku dan produk
ISSN: 2443-1095

yang akan dihasilkan. Namun berbagai proses pengolahan dan penambahan bahan lainnya dapat mempengaruhi rasa dari suatu produk. Hubungan pengaruh lama pemanasan (perebusan) dengan rasa sirup kersen dapat dilihat pada Gambar 5.

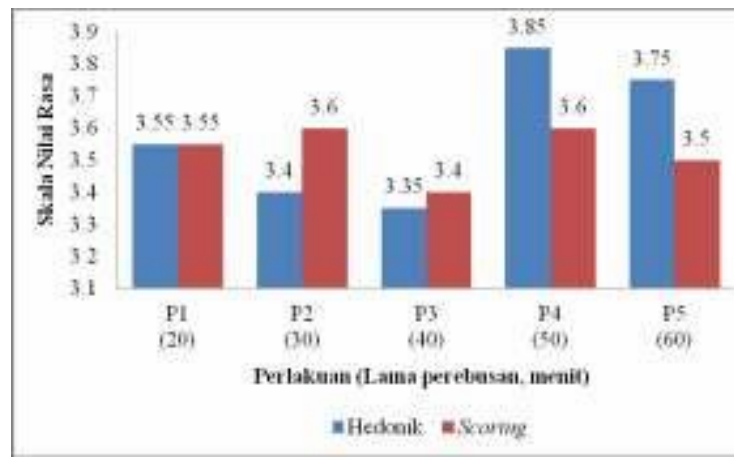

\section{Gambar 5. Grafik Pengaruh Lama Pemanasan (Perebusan) terhadap Rasa Sirup Kersen}

Berdasarkan Gambar 5, menunjukkan bahwa perlakuan lama pemanasan (perebusan) memberikan pengaruh yang tidak berbeda nyata terhadap rasa sirup kersen yang dihasilkan dengan uji hedonik maupun uji scoring. Hal ini disebabkan karena dalam proses pembuatan sirup kersen penggunaan bahan seperti buah kersen, gula, asam sitrat dan CMC ditambahkan dengan perbandingan yang sama. Penilaian uji hedonik, rata-rata panelis memberikan nilai agak suka terhadap rasa sirup kersen dengan kisaran 3,35-3,85 dengan nilai tertinggi pada perlakuan P4 dengan lama pemanasan 50 menit.

Pada penilain uji scoring, panelis memberikan nilai agak manis terhadap rasa sirup kersen nilai 3,4-3,6 dengan nilai tertinggi pada perlakuan P2 dan P4 dengan lama pemanasan 30 menit dan 50 menit. Rasa sirup kersen yang manis disebabkan karena buah kersen yang digunakan adalah buah kersen matang berwarna merah. Buah kersen matang memiliki kandungan gula lebih tinggi dibandingkan buah kersen mentah karena selama proses pematangan terjadi pemecahan karbohidrat (pati) menjadi glukosa. Selain itu, penambahan gula pasir (sukrosa) pada proses pembuatan sirup juga dapat menimbulkan rasa manis pada sirup kersen yang dihasilkan. Semakin lama pemanasan sukrosa yang terinversi menjadi glukosa dan fruktosa semakin tinggi sehingga sirup akan semakin manis.

\section{Aroma}

Penerimaan konsumen terhadap suatu produk diawali dengan penilaiannya terhadap 
Versi Online:

http://www.profood.unram.ac.id/index.php/profood e-ISSN: 2443-3446

penampakan, flavor dan tekstur. Aroma merupakan salah satu sifat sensoris yang menentukan penerimaan konsumen terhadap suatu produk. Aroma dari produk yang telah mengalami proses pengolahan seharusnya sesuai dengan aroma bahan baku utama yang digunakan. Hal ini berkaitan dengan ciri khas dan konsistensi dari bahan baku dan produk yang akan dihasilkan. Adanya aroma yang menyimpang pada suatu produk dapat menjadi indikator adanya kerusakan mutu dan proses pengolahan yang kurang baik. Hubungan pengaruh lama pemanasan (perebusan) dengan aroma sirup kersen dapat dilihat pada Gambar 6.

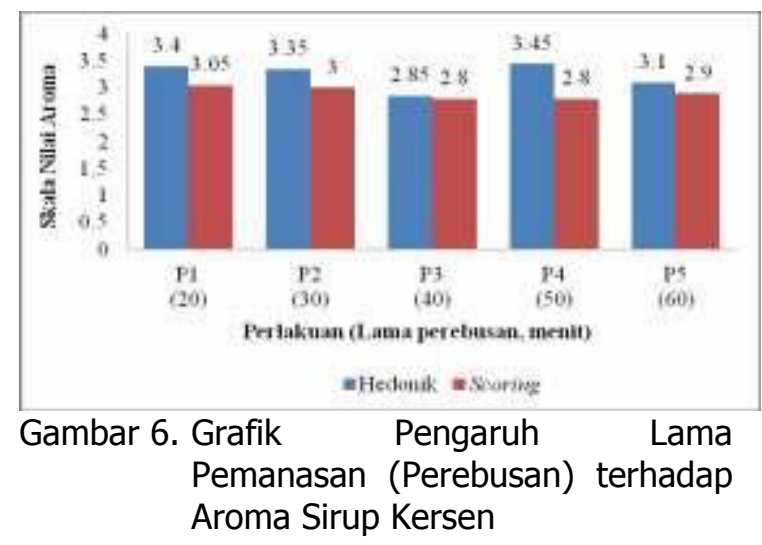

Berdasarkan Gambar 6, menunjukkan bahwa perlakuan lama pemanasan (perebusan) memberikan pengaruh yang tidak berbeda nyata terhadap aroma sirup kersen yang dihasilkan dengan uji hedonik maupun uji scoring. Hal ini disebabkan karena dalam proses pembuatan sirup kersen penggunaan bahan seperti buah kersen, gula, asam sitrat dan CMC ditambahkan dengan perbandingan yang sama.

Penilaian uji hedonik, rata-rata panelis memberikan nilai netral terhadap aroma sirup kersen dengan kisaran 2,85-3,45 dengan nilai tertinggi pada perlakuan P4 dengan lama pemanasan 50 menit. Pada penilain $\mathrm{uji}$ scoring, panelis memberikan nilai agak khas kersen terhadap aroma sirup kersen dengan kisaran nilai 2,8-3,05 dengan nilai tertinggi pada perlakuan $\mathrm{P} 1$ dengan lama pemanasan 20 menit. Aroma sirup yang agak khas kersen disebabkan karena bahan baku utama yang digunakan dalam pembuatan sirup adalah buah kersen matang berwarna merah. Senyawa kimia utama dalam aroma buah adalah ester dari alkohol alifatik dan asamasam lemak berantai pendek. Senyawa volatil diproduksi dan dikeluarkan oleh buah hanya apabila buah mulai matang.

\section{Pro Food (Jurnal IImu dan Teknologi Pangan) \\ Vol 4 No. 1 Mei 2018 ISSN: 2443-1095}

\section{KESIMPULAN}

Berdasarkan hasil analisis dan uraian pembahasan yang terbatas pada lingkup penelitian ini maka dapat disimpulkan bahwa perlakuan lama pemanasan (perebusan) memberikan pengaruh yang berbeda nyata (signifikan) terhadap kadar vitamin C, aktivitas antioksidan, $\mathrm{pH}$ dan kadar gula reduksi namun memberikan pengaruh yang tidak berbeda nyata (non signifikan) terhadap sifat sensoris rasa dan aroma (uji hedonik dan scoring) sirup kersen. Semakin lama waktu pemanasan (perebusan), maka kadar vitamin C, aktivitas antioksidan dan $\mathrm{pH}$ sirup kersen semakin menurun namun kadar gula reduksi sirup kersen semakin meningkat. Perlakuan lama pemanasan (perebusan) 20 menit merupakan perlakuan terbaik karena menghasilkan sirup kersen dengan kadar vitamin C tertinggi, yaitu $28,09 \mathrm{mg} / 100 \mathrm{~g}$ bahan, aktivitas antioksidan tertinggi, yaitu $51,79 \%$, kadar gula reduksi $7,95 \%$, pH 4,28, rasa agak manis dan aroma agak khas kersen.

\section{DAFTAR PUSTAKA}

Anonim. 2017. Teori Dasar pH. http://repository.usu.ac.id/bitstream/ 123456789/18255/3/chapter\%20ii.pdf [03 November 2017].

AOAC. 1999. Official Methods of Analysis of The Association Analytical Chemistry, Inc., Washington D. C.

Badan Standardisasi Nasional (BSN). 2004. Penentuan Kadar pH. SNI 066989. 11- 2004. Badan StandardisasiNasional. Jakarta. https://tuxdoc.com/ download/sni06-698911-2004-ph-meter-pdf-\# download-require[22 Februari 2018].

Badan Standardisasi Nasional (BSN), 2013. Sirup. SNI 3544:2013. Badan Standardisasi Nasional. Jakarta. https://kupdf.com/download/snisirup 58ec4250dc0d608178da9810 pdf [03 November 2017].

Blois, M. S., 1958. Antioxidant Determination by The Use of Stabel Free Radical, Nature 181. HIm. $1199-1299$. https://media.neliti.com/media/publi cations/124923-

Daktivitasantioksidan-danantibakteriek.pdf [03 November 2017]. 
Versi Online:

http://www.profood.unram.ac.id/index.php/profood e-ISSN: 2443-3446

Buckle KA, Edwars RA, Fleet GH dan Wootton M. (Penerjemah Hari Punomo dan Adiono). 2013. Ilmu Pangan. Universitas Indonesia, Jakarta.

deMan JM. 1997. Kimia Pangan. Terjemahan Kosasih Padmawinata. Institut Teknologi Bandung Press, Bandung.

Frei, 1994. Reactive oxygen species and antioxidant vitamins: mechanisms of action. American Journal Medicine: 97- 107.

Gomathi R, Anusuya N, dan Manian S. 2013. A dietary antioxidant supplementation of jamaican cherries (Muntingia calabura L.) Attenuates Inflammatory Related Disorders. Food Sci Biotechnol 22(3): 787-794.

Hadiwijaya H. 2017. Pengaruh Perbedaan Penambahan Gula Terhadap Karakteristik Sirup. http://repository.unand.ac.id/20528/ 1/Jur nal.pdf. [25 September 2017].

Hanafiah KA. 2005. Rancangan Percobaan Aplikatif. PT. Raja Grafindo Persada, Jakarta.

Handayani S. 2011. Pembuatan Sirup Markisa dan Terong Belanda (Martebe) Sebagai Sumber Vitamin C Bagi Tubuh. $\quad$ eprints.uny.ac.id /41121/1/Sri\%20Handayani\%20$\% 2007512134020$.pdf [25 September 2017].

Harnowo I dan Yunianta. 2015. Penambahan ekstrak biji buah pinang dan asam sitrat terhadap sifat fisik, kimia dan organoleptik sari buah belimbing manis. J Pangan dan Agroindustri, 3 (3): 1241-1251.

Hartiati A, Sri M dan Made DP. 2009. Pengaruh preparasi bahan baku rosella dan waktu pemasakan terhadap aktivitas antioksidan sirup bunga rosella (Hisbiscus sabdariffa L.). Agrotekno, 15 (1): 20-24.

Indrayani E. 2012. Mudah dan Praktis Membuat Aneka Sirop Buah-Buahan. PT Wahyu Media, Jakarta.

Lozano JE. 2006. Fruit Manufacturing: Scientific basis, Engineering properties, and deteriorative reaction of technological importance. Springer Science + Business Media
Pro Food (Jurnal Ilmu dan Teknologi Pangan)

Vol 4 No. 1 Mei 2018 ISSN: 2443-1095

LLC.http://197.14.51.10:81/ pmb/BIOLOGIE/Fruit\%20Manufacturi ng.pdf [15 Desember 2016].

Maghribi RH. 2013. Pengaruh Pemberian Jus Buah Kersen (Muntingia calabura) terhadap Kadar Trigliserida pada Tikus Sprague Dawley Dislipidemia. [Skripsi]. Yogyakarta: Universitas Gadjah Mada.

Nurrahman, Siti A, Nurhidajah, Wikanastri, Agus S, dan Muhammad Y. 2006. Pengujian Organoleptik (Evaluasi Sensoris) dalam Industri Pangan. http://tekpan.unimus.ac.id/wpcontent/uploads/2013/0/7 Pengujian-Organoleptik-dalamIndustri-Pangan.pdf [15 Desember 2016].

Octaviani LF. 2014. Pengaruh Berbagai Konsentrasi Gula terhadap Aktivitas Antioksidan dan Tingkat Penerimaan Sari Buah Buni (Antidesma bunius). [Skripsi]. Semarang: Universitas Diponogoro.

Osawa T dan MA Namiki. 1981. A novel type of antioxidant isolated from leaf wax of eucalyptus leaves. Agric Biol Chem, 45: 735 - 739.

Pramono VJ dan Santoso R. 2014. Pengaruh ekstrak buah kersen (Muntingia calabura) terhadap kadar gula darah tikus putih (Rattus novergicus) yang diinduksi Streptozotocin (STZ). J Sains Veteriner. 32(2): 218223.download.portalgaruda.org Larticle.php?article $=356138 \& v a l=298$ \&title [diakses 25 September 2017].

Rahman A, Fardiaz S, Suliantari WPR dan Nurwitri CC. 1992. Teknologi Pengolahan Susu. Depdikbud Dirjen PT. Pusat Antar Universitas Pangan dan Gizi IPB. Bogor.

Rahman M, Fakir SA dan Rahman M. 2010. Fruit growth of china cherry (Muntingia calabura). Botany Research International, 3(2): 56-60.

Satuhu S.1994. Penanganan dan Pengolahan Buah. Penebar Swadaya, Jakarta.

Sudarmadji S, Hariyono B dan Suhardi. 2010. Prosedur Analisa untuk Bahan Makanan dan Pertanian. Liberty, Yogyakarta. 
Versi Online:

http://www.profood.unram.ac.id/index.php/profood e-ISSN: 2443-3446

Trissanthi CM dan Wahono HS. 2016. Pengaruh konsentrasi asam sitrat dan lama pemanasan terhadap karakteristik kimia dan organoleptik sirup alang-alang (Imperata cylindrica). J Pangan dan Agroindustri, 4(1): 180-189.
Pro Food (Jurnal Ilmu dan Teknologi Pangan)

Vol 4 No. 1 Mei 2018 ISSN: 2443-1095

Verheij EWM dan Coronel RE. 1997. Sumber Daya Nabati Asia Tenggara 2 BuahBuahan Yang Dapat Dimakan. PT Gramedia Pustaka Utama, Jakarta. 